Article

\title{
Heat and Mass Transfer Properties of Sugar Maple Wood Treated by the Thermo-Hygro-Mechanical Densification Process
}

\author{
Qilan Fu ${ }^{1}$, Alain Cloutier ${ }^{1, *}$ and Aziz Laghdir ${ }^{2}$ \\ 1 Center de Recherche sur les Matériaux Renouvelables (Renewable Materials Research Center), Département \\ des Sciences du Bois et de la Forêt (Department of Wood and Forest Science), Université Laval, Québec, \\ QC G1V 0A6, Canada; qilan.fu.1@ulaval.ca \\ 2 Research Scientist, Service de Recherche et D'expertise en Transformation des Produits Forestiers \\ (Research and Expertise Service on Transformation of Forest Products), Amqui, QC G5J 1K3, Canada; \\ aziz.laghdir@serex.qc.ca \\ * Correspondence: alain.cloutier@sbf.ulaval.ca; Tel.: +1-418-656-5851
}

Received: 29 June 2018; Accepted: 17 July 2018; Published: 24 July 2018

\begin{abstract}
This study investigated the evolution of the density, gas permeability, and thermal conductivity of sugar maple wood during the thermo-hygro-mechanical densification process. The results suggested that the oven-dry average density of densified samples was significantly higher than that of the control samples. However, the oven-dry density did not show a linear increase with the decrease of wood samples thickness. The radial intrinsic gas permeability of the control samples was 5 to 40 times higher than that of densified samples, which indicated that the void volume of wood was reduced notably after the densification process. The thermal conductivity increased by 0.5-1.5 percent for an increase of one percent moisture content for densified samples. The thermal conductivity of densified wood was lower than that of the control samples. The densification time had significant effects on the oven-dry density and gas permeability. Both densification time and moisture content had significant effects on thermal conductivity but their interaction effect was not significant.
\end{abstract}

Keywords: density; gas permeability; thermal conductivity; densification

\section{Introduction}

The heat and mass transfer properties of wood or wood-based materials are essential characteristics required for a variety of purposes, including the heat and mass transfer modeling during the densification process and characterization of densified wood as a building material. Among others, typical properties required are density, permeability, and thermal conductivity. A proper characterization of these properties is crucial for increasing the accuracy of model predictions. However, during the thermo-hygro-mechanical (THM) densification process, density, permeability, and thermal conductivity of wood are all time-dependent, which makes the characterization of these parameters difficult.

Bulk flow is the principal mechanism for the transport of fluids through wood, which occurs through the voids of the wood under a static or capillary pressure gradient [1]. The bulk flow rate of fluids is determined by wood permeability. During the hot-pressing process of wood composite materials, the gas permeability controls the convective heat transfer from surface layers to the core layer and impacts the movement of the vapor from the core to the edges [2]. Since gas permeability depends largely on the pore structure of the fiber or particle mat, the densification treatment should have a direct effect on the permeability. Comstock [3] reported that the arrangement of wood principal directions has more impact on its gas permeability than any other parameter. In some species, the longitudinal 
permeability could be $10^{6}$ higher than in the transverse direction, due to the arrangement of the wood cells.

A few researchers investigated the gas permeability of wood based panels using experimental methods [4-8]. Almost all the methods described in the literature are based on measuring the amount of gas flow at a given pressure gradient applied across the sample. Defo et al. [9] measured radial and tangential gas permeability values of sugar maple wood at $12 \%$ of moisture content (MC) (oven-dry density varied from 587 to $676 \mathrm{~kg} / \mathrm{m}^{3}$ ) between $2.04 \times 10^{-17} \mathrm{~m}_{\text {air }}^{3} \mathrm{~m}_{\text {wood }}^{-1}$ and $2.84 \times 10^{-17} \mathrm{~m}_{\text {air }}^{3} \mathrm{~m}_{\text {wood }}^{-1}$. Von Haas et al. [6] reported that the MC had almost no effect on gas permeability for low density samples and a slight effect on samples with a density above $900 \mathrm{~kg} / \mathrm{m}^{3}$. Moreover, air permeability was at least two orders of magnitude higher than steam permeability, which might be due to the swelling of wood and the viscosity of the fluid on the superficial permeability $[4,10]$.

Thermal conductivity is an important material property in determining the heat transfer rate [11]. The thermal conductivity of wood is affected by several basic factors: density, temperature, MC, extractive content, grain direction, structural irregularities, such as checks, and knots and microfibril angle, among which density and MC are predominant [12]. Troppová et al. [13] found that higher temperatures resulted in larger differences between the thermal conductivity values of wood-based fiberboards in the oven dry condition and at $14.2 \% \mathrm{MC}$. Thermal conductivity in the radial direction was reported to be about $5 \%$ to $10 \%$ higher than in the tangential direction [14]. Thermal conductivity along the grain has been reported to be 1.5 to 2.8 times higher than across the grain but the reported values vary widely. For example, Maclean [15] found that the thermal conductivity along the longitudinal direction is about 2.25 to 2.75 times higher than transverse thermal conductivity with an average of approximately 2.5 .

The steady-state method is normally applied to measure the thermal conductivity of wood [16]. A large number of empirical equations could be found in the literature, to describe the relationship between wood thermal conductivity, density, and MC $[1,10,15,17]$. However, these empirical equations are applicable only within a limited range of $\mathrm{MC}$ and density levels. Hence, these relations may not be appropriate to describe the variation of the thermal conductivity of wood undergoing THM densification because both MC and density vary continuously during the process. In addition, little empirical data were found for the thermal conductivity of sugar maple wood at different density levels. Therefore, the objective of the current study was to investigate the variation of density, gas permeability, and thermal conductivity of sugar maple wood during the THM densification process.

\section{Materials and Methods}

Sugar maple (Acer saccharum Marsh) wood was selected for this study. This species is a diffuse-porous hardwood normally used for in-door applications such as flooring and furniture [18]. Thin sawn strips of sugar maple wood were provided by a hardwood flooring plant (Lauzon, Distinctive Hardwood Flooring Inc., Papineauville, QC, Canada). Their average apparent density $\left(20{ }^{\circ} \mathrm{C}\right.$ and $65 \%$ relative humidity $\left.(\mathrm{RH})\right)$ was 734 (standard deviation: 8.4$) \mathrm{kg} / \mathrm{m}^{3}$ and their dimensions were $5.7 \mathrm{~mm}$ (radial) $\times 84.0 \mathrm{~mm}$ (tangential) $\times 695.0 \mathrm{~mm}$ (longitudinal). When they were received, the strips were stored in a conditioning room at $20{ }^{\circ} \mathrm{C}$ and $65 \% \mathrm{RH}$ until an equilibrium moisture content of approximately $12 \%$ was achieved. Ten groups of 8 strips were densified for $0 \mathrm{~min}$ (control sample), $5 \mathrm{~min}, 10 \mathrm{~min}, 15 \mathrm{~min}, 20 \mathrm{~min}, 25 \mathrm{~min}, 30 \mathrm{~min}, 35 \mathrm{~min}, 40 \mathrm{~min}$, and $45 \mathrm{~min}$, respectively. The strips were used for experimental determination of the evolution with time of density, gas permeability, and thermal conductivity during the THM densification process.

\subsection{Thermo-Hygro-Mechanical Densification Process}

A steam injection press (Dieffenbacher, Alpharetta, GA, USA) with dimensions of $862 \mathrm{~mm} \times 862 \mathrm{~mm}$ was used for the densification treatment (Figure 1). Steam injection holes with a diameter of $1.5 \mathrm{~mm}$ were distributed uniformly at $32 \mathrm{~mm}$ intervals on both the top and bottom platens of the press. To reduce wood surface carbonization and distribute the steam uniformly, both surfaces 
of the specimens were covered with a thin heat-resistant fabric permeable to steam made of Nomex ${ }^{\circledR}$ III A manufactured by Dupont ${ }^{\mathrm{TM}}$ [19]. The two press platens were preheated to the target temperature $\left(200^{\circ} \mathrm{C}\right)$ before treatment. The upper platen reached the specimens within $86 \mathrm{~s}$ during press closing.

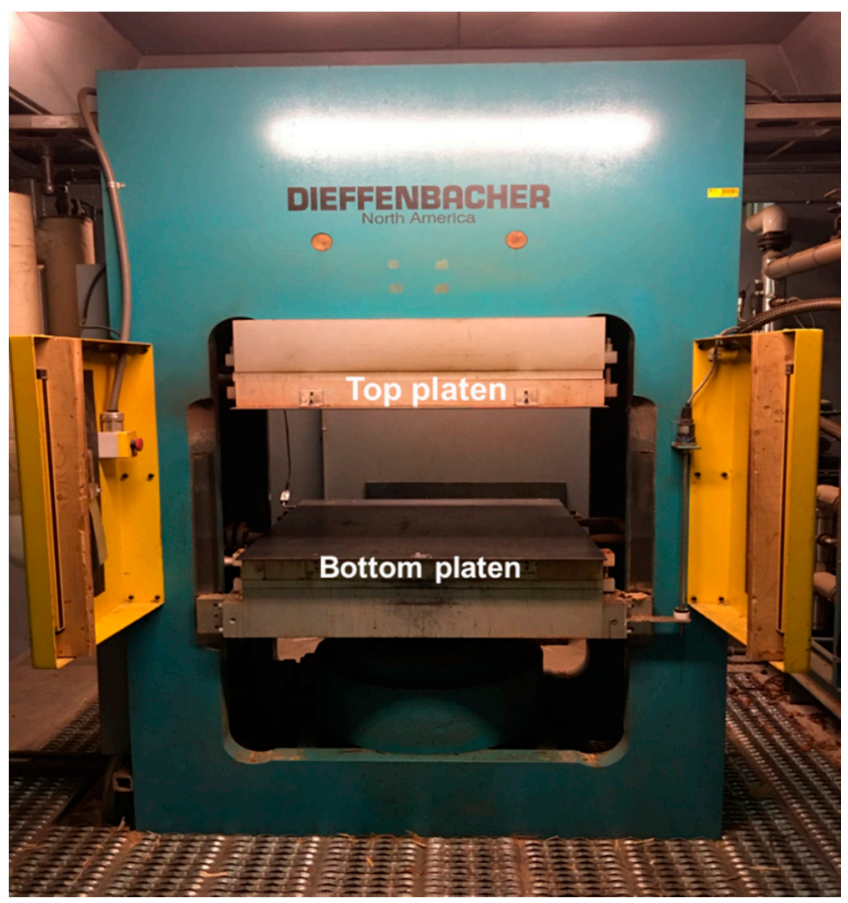

Figure 1. Steam injection hot press used for THM densification treatment.

For all of the treatments except for the control group, the densification process was pre-set in the computer control system. Steam was continuously injected during the whole process at a maximum manometer pressure of $550 \mathrm{kPa}$, while the specimens were pressed under an increasing mechanical manometer platen pressure up to $6 \mathrm{MPa}$ [20]. The evolution of steam pressure and platen pressure during the whole process is presented in Figure 2 [20]. The whole densification process was divided into ten steps according to the treatment time $(0 \mathrm{~min}, 5 \mathrm{~min}, 10 \mathrm{~min}, 15 \mathrm{~min}, 20 \mathrm{~min}, 25 \mathrm{~min}, 30 \mathrm{~min}$, $35 \mathrm{~min}, 40 \mathrm{~min}$, and $45 \mathrm{~min}$ ). The density, gas permeability, and thermal conductivity of all samples were determined for each treatment time in order to track their variation during the THM densification process. For the samples densified for $5 \mathrm{~min}$, the control system stopped the process $5 \mathrm{~min}$ after the two hot platens closed, even though the maximum platen pressure had not been reached [20]. For the other treatments, the control system stopped the process after $10 \mathrm{~min}, 15 \mathrm{~min}, 20 \mathrm{~min}, 25 \mathrm{~min}, 30 \mathrm{~min}$, $35 \mathrm{~min}, 40 \mathrm{~min}, 45 \mathrm{~min}$ respectively. In these cases, both the maximum steam pressure and platen pressure were reached. All the treated samples were then stored in a conditioning room at $20^{\circ} \mathrm{C}$ and $65 \% \mathrm{RH}$ until their equilibrium moisture content was reached prior to their properties determination. 


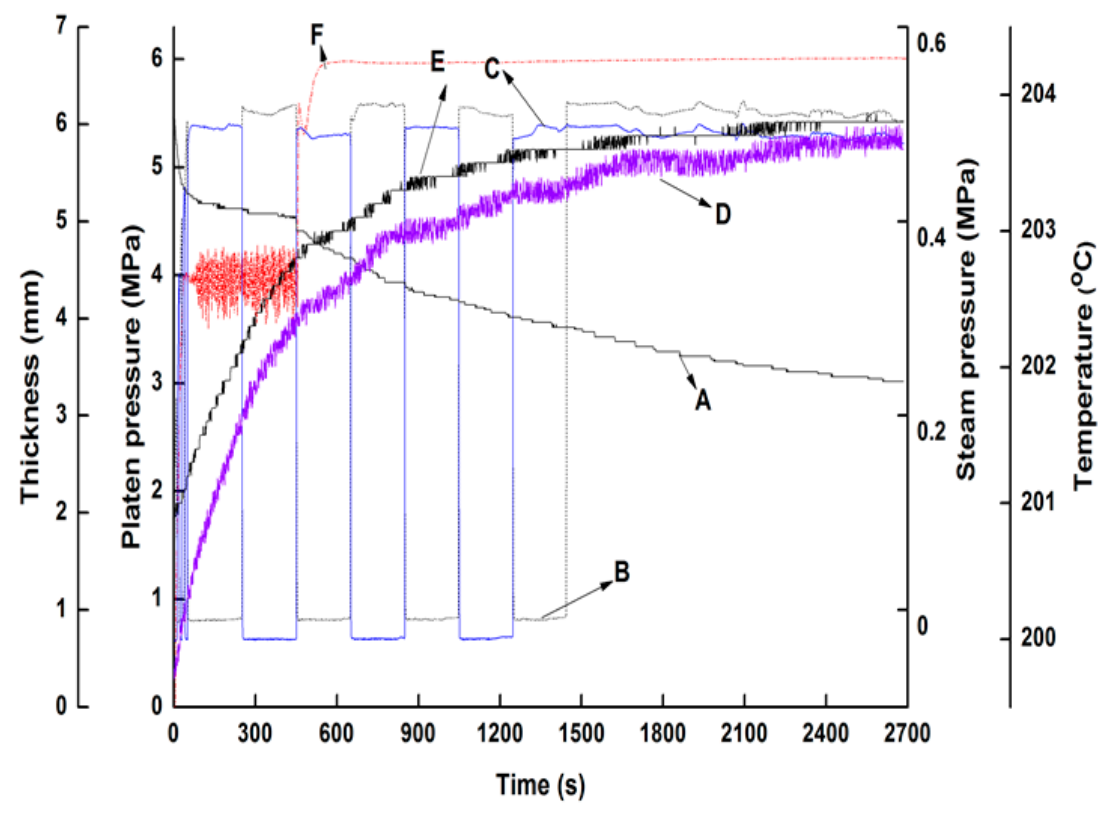

Figure 2. Thermo-hygro-mechanical densification process. A: Thickness; B, C: top and bottom platen steam pressure, respectively; D, E: top and bottom platen temperature; F: platen load.

\subsection{Properties Determination-Oven-Dry Average Density}

Three specimens for each densification time with dimensions $50 \mathrm{~mm} \times 50 \mathrm{~mm}$ were oven-dried and used to measure the density using an X-ray densitometer (Quintek Measurements Systems model QDP-01X, Knoxville, TN, USA) at intervals of $0.02 \mathrm{~mm}$ through the thickness. The average value $(n=3)$ was used as the final oven-dry density of each group.

\subsection{Permeability Measurement}

Three discs of $50 \mathrm{~mm}$ in diameter for each densification time were prepared for the gas permeability measurement. A special device developed in our laboratory by Lihra et al. [7] was used to measure the transverse gas permeability of the wood samples. The gas permeability was measured in this study with air using the apparatus shown in Figure 3. A cylinder of compressed air equipped with a pressure regulator was used to regulate the flow of gas at the desired pressure. In addition, a silicon seal was used on the edge of each disc in order to make a tight seal with a rubber sleeve surrounding it. A pressure of $600 \mathrm{kPa}$ was applied to the rubber sleeve to prevent air leaks through the specimen edge. Two basswood discs (Tilia americana) with high longitudinal gas permeability were placed both in the inlet and outlet sides of the specimen to distribute the air flow [8]. Five flowmeters (Figure 3) with increasing range were installed to measure the gas flow rate through the samples. For each measurement, the flowmeter with a larger range (flowmeter 5) was firstly used. If there was no value provided, it was closed and the next one was used. This procedure was repeated until the gas flow rate could be measured. Each disc ( $\mathrm{n}=3$ for each group) was measured at four pressure levels $(\Delta \mathrm{P}$-values measured from pressure gage B): $200 \mathrm{kPa}, 250 \mathrm{kPa}, 300 \mathrm{kPa}$, and $350 \mathrm{kPa}$, respectively. 


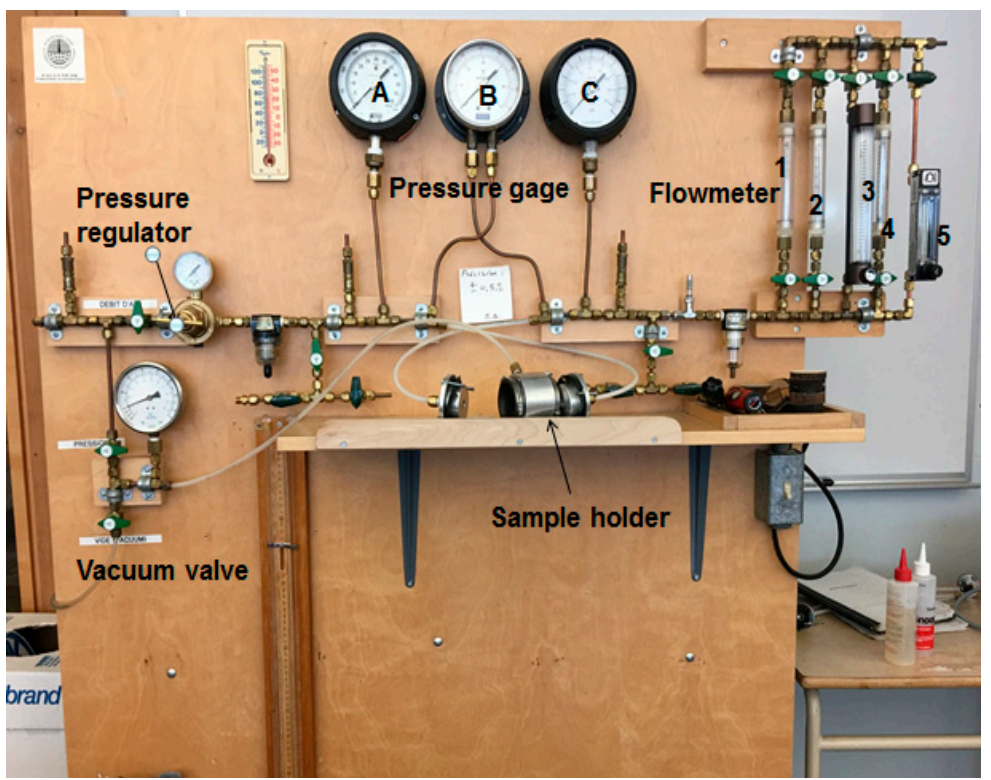

Figure 3. Apparatus used for gas permeability measurements.

The steady-state gas flow through wood can be characterized by Darcy's law. It could be stated as:

$$
\mathrm{k}_{\mathrm{p}}{ }^{*}=\frac{\mathrm{Q}_{\mathrm{g}} \mathrm{L}}{\mathrm{A}_{\mathrm{s}} \Delta \mathrm{P}} \overline{\overline{\mathrm{P}}}
$$

where $\mathrm{k}_{\mathrm{p}}{ }^{*}$ is apparent gas permeability with slip flow $\left(\mathrm{m}_{\text {gas }}^{3} \mathrm{~m}_{\text {wood }}^{-1} \mathrm{~s}^{-1} \mathrm{~Pa}^{-1}\right), \mathrm{Q}_{\mathrm{g}}$ is the volumetric gas flow rate $\left(\mathrm{m}^{3} / \mathrm{s}\right), \mathrm{L}$ is the length in the flow directioncorresponding to the thickness of the sample $(\mathrm{m}), \mathrm{A}_{\mathrm{s}}$ is gas flow area $\left(\mathrm{m}^{2}\right), \Delta \mathrm{P}$ is the pressure differential between the inlet side and outlet side $(\mathrm{Pa})$ $(\Delta \mathrm{P}=\mathrm{P} 1-\mathrm{P} 2), \mathrm{P} 1$ is the inlet air pressure $(\mathrm{Pa}), \mathrm{P} 2$ is the outlet air pressure $(\mathrm{Pa}), \mathrm{P}$ is the pressure at which $Q_{g}$ was measured $(\mathrm{Pa}), \overline{\mathrm{P}}$ is the arithmetic average pressure $(\mathrm{Pa}), \overline{\mathrm{P}}=\frac{\left(\mathrm{P}_{1}+\mathrm{P}_{2}\right)}{2}$.

The apparent gas permeability $\mathrm{k}_{\mathrm{p}}{ }^{*}$ from Equation (1) includes Knudsen diffusion, also called slip flow. When a gas flows through a capillary whose diameter is in the same order of magnitude as the average free path between the gas molecules, slip flow becomes significant and must be considered in the permeability measurement. The gas permeability corrected for slip flow could be obtained from the Klinkenberg equation [21]:

$$
\begin{gathered}
\mathrm{k}_{\mathrm{p}}{ }^{*}=\mathrm{k}_{\mathrm{p}} \times \mathrm{s} \\
\mathrm{s}=1+\frac{3.8 \lambda}{\mathrm{r}} \\
\lambda=\frac{2 \mu}{\overline{\mathrm{P}}} \sqrt{\frac{\mathrm{RT}}{\mathrm{M}_{\mathrm{a}}}} \\
\mathrm{K}=\mathrm{k}_{\mathrm{p}} \times \mu
\end{gathered}
$$

where $k_{p}$ is the apparent gas permeability corrected for slip flow $\left(\mathrm{m}_{\text {gas }}^{3} \mathrm{~m}_{\text {wood }}^{-1} \mathrm{~s}^{-1} \mathrm{~Pa}^{-1} \mathrm{~Pa}\right), \mathrm{s}$ is the slip flow factor, $\lambda$ is the average free path between gas molecules $(\mathrm{m}), \mathrm{r}$ is the diameter of the capillary, $R$ is the universal gas constant $(8.31 \mathrm{~J} / \mathrm{mol} / \mathrm{K}), T$ is the absolute temperature $(K), M_{a}$ is the molecular weight of air $(\mathrm{kg} / \mathrm{mol}) . \mathrm{K}$ is the intrinsic gas permeability $\left(\mathrm{m}_{\text {gas }}^{3} \mathrm{~m}_{\text {wood }}^{-1}\right), \mu$ is viscosity of fluid $(\mathrm{Pa} \cdot \mathrm{s})$ (for air at room temperature $\mu=1.845 \times 10^{-5} \mathrm{~Pa} \cdot \mathrm{s}$ ). $\mathrm{k}_{\mathrm{p}}$ represents the "true" gas permeability corrected for slip flow and can be determined graphically from the intercept of a plot of $\mathrm{k}_{\mathrm{p}}{ }^{*}$ against the reciprocal average pressure $(1 / \overline{\mathrm{P}})[7,21]$. 


\subsection{Thermal Conductivity Measurement}

Four specimens for each densification time with dimensions $152.4 \mathrm{~mm} \times 170.0 \mathrm{~mm}$ were prepared for thermal conductivity measurement using the apparatus LaserComp Fox 314 (TA instruments, New Castle, DE, USA) shown in Figure 4a. The Fox 314 instrument was designed according to the ASTM C518-04 standard test method for steady-state thermal transmission properties by means of the heat flow meter apparatus. The specimen was placed between two heating plates (Figure $4 \mathrm{~b}$ ) with different temperature for a sufficient length of time to obtain a uniform temperature gradient throughout the sample. The temperature of the upper heating plate was set at $10^{\circ} \mathrm{C}$ and that of the base heating plate was set at $35^{\circ} \mathrm{C}$. The temperature equilibrium of the system is considered to be reached when the temperatures of the two plates are stable within $\pm 0.2{ }^{\circ} \mathrm{C}$ after the set point has been reached. During the test, the auto thickness mode was selected, and the sample's thickness was determined automatically by the instrument's digital thickness measurement system.
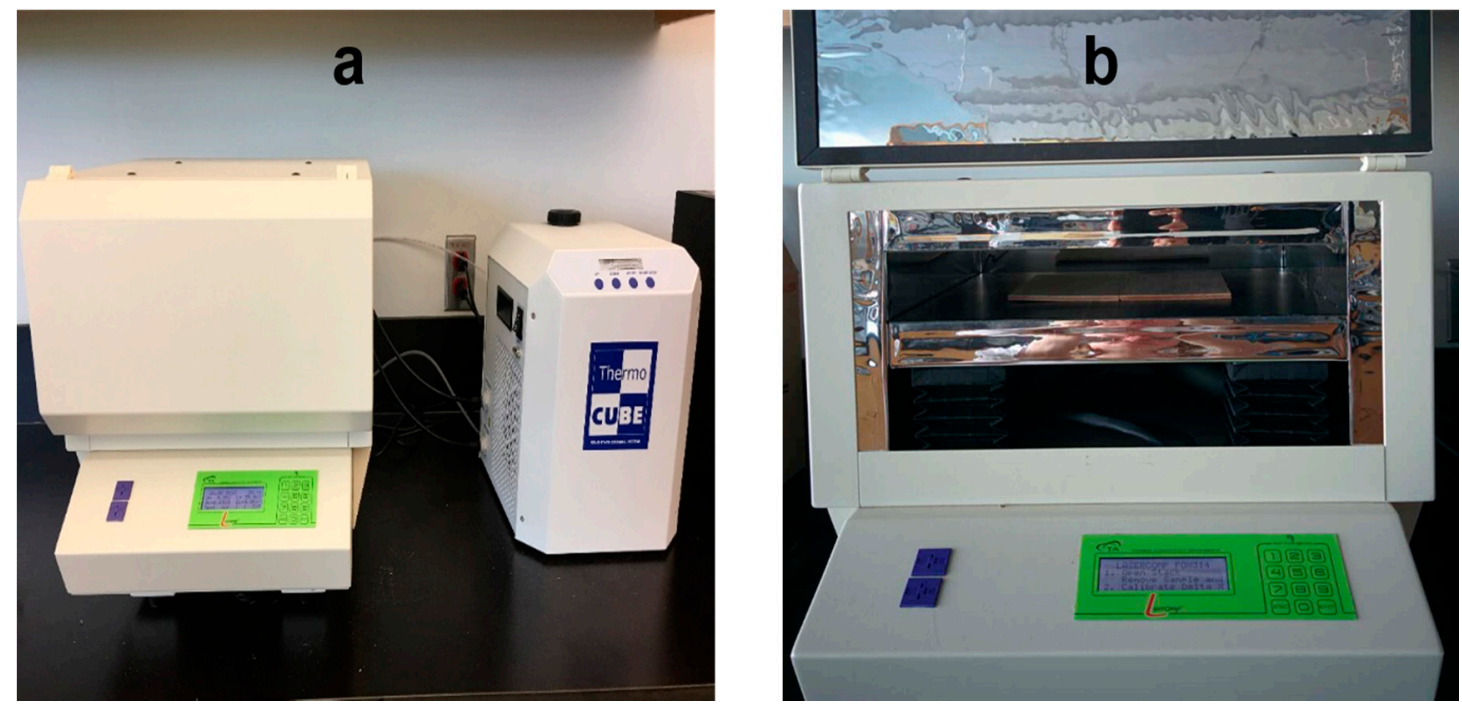

Figure 4. (a) Thermal conductivity testing apparatus; (b) Position of the sample and two heating plates.

The thermal conductivity is significantly affected by MC. To investigate the influence of MC on the thermal conductivity, each specimen ( $\mathrm{n}=4$ for each group) was measured at three moisture content levels $(0 \%, 6 \%$, and $12 \%)$, respectively. Finally, the thermal conductivity was described as a function of densification time and MC.

\subsection{Statistical Analysis}

An analysis of variance (ANOVA) was performed to investigate the effect of densification time on the oven-dry density and gas permeability, and the effects of the densification time and MC on the thermal conductivity of densified sugar maple wood using SAS 9.4 (SAS Institute Inc., Cary, NC, USA) at significance level $\alpha=0.05$. Duncan's test was conducted for multiple comparisons between average values obtained under different treatments.

\section{Results}

\subsection{Density Profile and Oven-Dry Density}

Typical density profiles of the control sample (densification time $=0 \mathrm{~min}$ ) and samples densified for $10 \mathrm{~min}$ and $40 \mathrm{~min}$, respectively, were selected to investigate the density distribution of sample through its thickness undergoing different densification time treatments. As shown in Figure 5, the density of the control sample was almost constant throughout the thickness, with the exception of 
the lower density values observed on both surfaces. The samples densified for $10 \mathrm{~min}$ showed a higher density in the core than at the surface, this might have been caused by the large spring back after the press opening. In our previous research [22], the density profile of the samples densified at lower temperatures $\left(180^{\circ} \mathrm{C}\right.$ and $\left.190^{\circ} \mathrm{C}\right)$ without steam showed similar tendency. This result also suggested that densification for $10 \mathrm{~min}$ was not enough, as the compressed deformation was not stable. The compressed sample surface experienced large springback, resulting in a non-homogeneous density distribution. The density was more homogeneous in the core for the samples densified for $40 \mathrm{~min}$, and a higher density at the surface than in the core was found. These observations were the same for samples densified at $200{ }^{\circ} \mathrm{C}$ with steam [22]. The heat distribution across the transverse direction was likely more homogeneous for samples densified for longer time with steam.

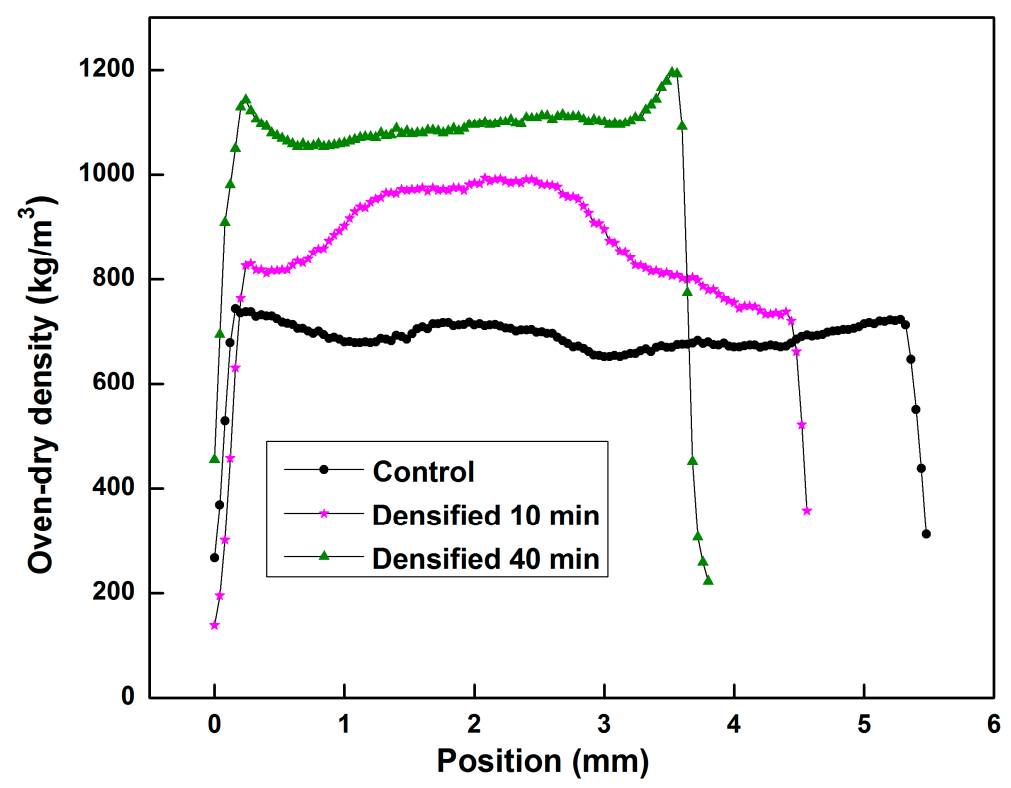

Figure 5. Typical density profile of wood samples densified at different time.

Analysis of variance results of average oven-dry density versus densification time are presented in Table 1. The results show that the densification time had a significant effect on the oven-dry density $(p=0.0002)$. Table 2 presents the evolution of the oven-dry density and thickness of the samples during the THM densification process. It can be seen that the thickness of the samples decreases in general with densification time. Most of the thickness reduction occurred within the first 5-15 min. This main reduction of thickness may be caused by the decrease of the void volume, and consequently resulted in an increase of the oven-dry density. However, the oven-dry density did not present a linear increase with the decrease of thickness. When the densification time is over $40 \mathrm{~min}$, the oven-dry density decreased, which might be due to the degradation of wood components for longer densification time at $200{ }^{\circ} \mathrm{C}$, resulting in a decrease in the overall density [19].

Table 1. Analysis of variance results of oven-dry density versus densification time.

\begin{tabular}{ccccccc}
\hline Source & $\begin{array}{c}\text { Sum of } \\
\text { Squares }\end{array}$ & $\begin{array}{c}\text { Degrees of } \\
\text { Freedom }\end{array}$ & $\begin{array}{c}\text { Mean } \\
\text { Square }\end{array}$ & $\boldsymbol{F}$ Value & $\boldsymbol{p}$ Value & Remarks \\
\hline Densification time & $280,224.4$ & 9 & $31,136.0$ & 6.8 & 0.0002 & Significant \\
\hline
\end{tabular}


Table 2. Oven-dry density of the control and samples densified at different time.

\begin{tabular}{ccc}
\hline Treatment Time (min) & Thickness $(\mathbf{m m})(\mathbf{n}=\mathbf{3})$ & Oven-Dry Density $\left(\mathbf{k g} / \mathbf{m}^{\mathbf{3}}\right) \mathbf{( n = 3 )}$ \\
\hline 0 & $5.63(0.11)$ & $694.3(4.1)^{\mathrm{c}, *}$ \\
5 & $4.49(0.15)$ & $848.6(82.8)^{\mathrm{b}}$ \\
10 & $4.26(0.04)$ & $845.4(76.1)^{\mathrm{b}}$ \\
15 & $3.81(0.09)$ & $917.3(61.0)^{\mathrm{a}, \mathrm{b}}$ \\
20 & $3.8(0.10)$ & $948.3(106.2)^{\mathrm{a}, \mathrm{b}}$ \\
25 & $3.63(0.04)$ & $947.1(43.5)^{\mathrm{a}, \mathrm{b}}$ \\
30 & $3.6(0.07)$ & $952.7(81.9)^{\mathrm{a}, \mathrm{b}}$ \\
35 & $3.68(0.06)$ & $1039.6(60.6)^{\mathrm{a}}$ \\
40 & $3.57(0.09)$ & $1031.6(44.2)^{\mathrm{a}}$ \\
45 & $3.51(0.08)$ & $969.5(65.6)^{\mathrm{a}, \mathrm{b}}$
\end{tabular}

Values in parenthesis are standard deviations; * Duncan's test results, average values with the same letter indicate no significant difference at $\alpha=0.05$.

\subsection{Gas Permeability}

A plot of $\mathrm{k}_{\mathrm{p}}{ }^{*}$ against $1 / \overline{\mathrm{P}}$ was made for each sample to correct the effect of slip flow. Figure 6 presents a typical relationship of $\mathrm{k}_{\mathrm{p}}{ }^{*}$ against $1 / \overline{\mathrm{P}}$ for radial flow in a control sample. A linear relationship can be observed in Figure 6 with a small but significant slope indicating the occurrence of slip flow. Therefore, the measured values of $\mathrm{k}_{\mathrm{p}}{ }^{*}$ should be corrected for slip flow to obtain the gas permeability $\mathrm{k}_{\mathrm{p}}$ from the intercept of the plot of $\mathrm{k}_{\mathrm{p}}{ }^{*}$ against $1 / \overline{\mathrm{P}}[7,21]$.

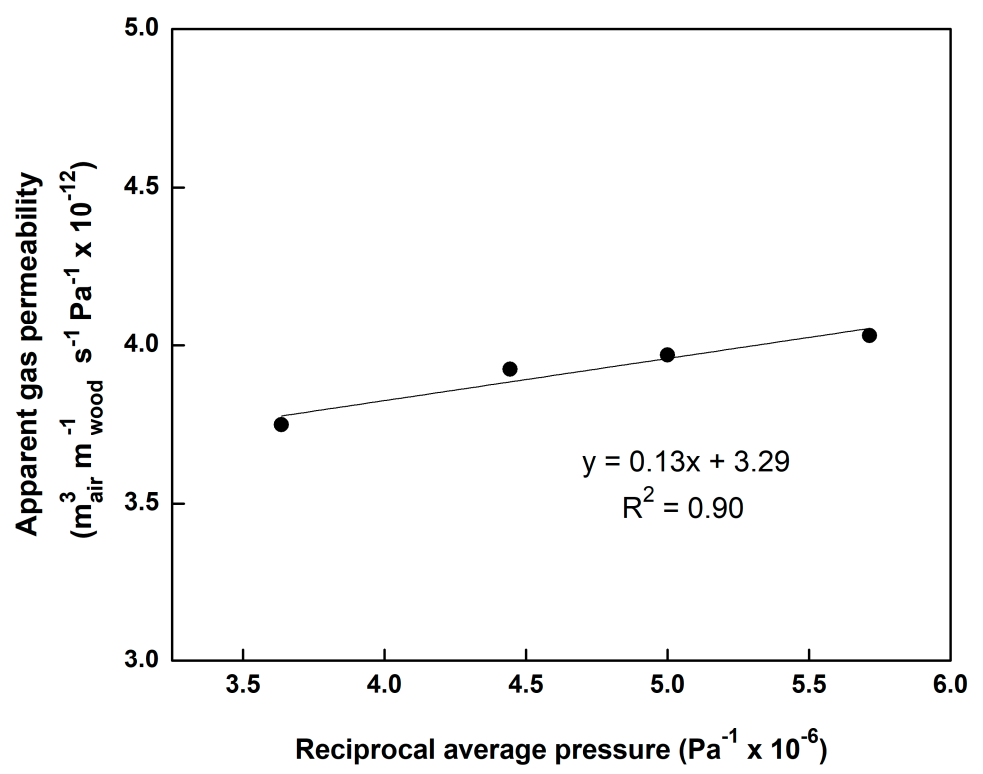

Figure 6. Typical relationship of the apparent gas permeability against the reciprocal average pressure for radial flow of the control sample.

The evolution of radial intrinsic gas permeability during the THM densification process is presented in Figure 7. Analysis of variance results of intrinsic gas permeability versus densification time are presented in Table 3. Table 4 presents the intrinsic gas permeability values of the control and densified samples, and the results of Duncan's test for all of the treatments.

The radial intrinsic gas permeability of the control sugar maple wood sample with an average oven-dry density of $694.3 \mathrm{~kg} / \mathrm{m}^{3}$ is $5.93 \times 10^{-17} \mathrm{~m}_{\text {air }}^{3} \mathrm{~m}_{\text {wood. }}^{-1}$. As shown in Figure 7 and Table 4, the intrinsic gas permeability of wood decreased rapidly at the beginning of the densification treatment compared with that of the control sample. However, no statistical difference was found between the intrinsic gas permeability of samples densified at 5, 10, and $15 \mathrm{~min}$, which might be due to their 
densities which were not significantly different. From 20 to $45 \mathrm{~min}$, the intrinsic gas permeability decreased with increasing of densification time. The intrinsic gas permeability of the control sample could be 5 to 40 times higher than for densified samples, which suggested that the void volume of wood reduced notably after densification. This might be due to the large difference between the radial intrinsic gas permeability of the control and densified samples, the whole data did not meet the assumption of a normal distribution. After performing normality test using SAS, it was found that a logarithm transformation $\left(\log _{10}\right)$ was needed. Table 3 revealed that the densification time had also a significant effect on wood permeability $(p<0.0001)$.

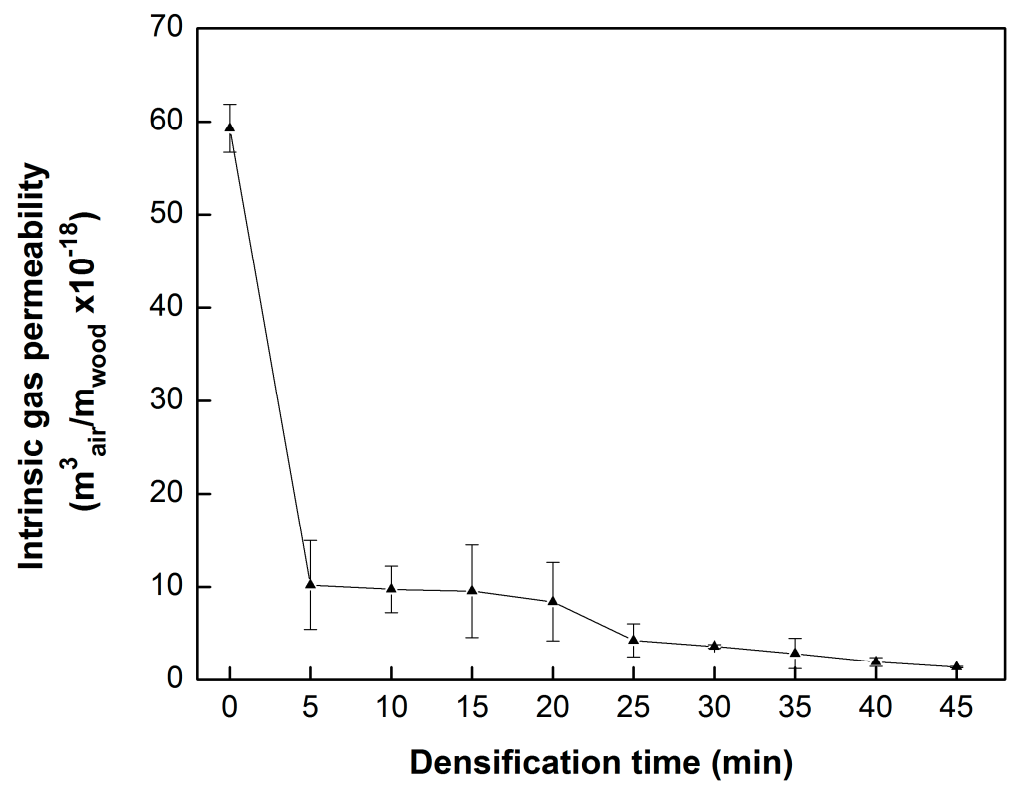

Figure 7. Evolution of the radial intrinsic gas permeability during the densification process.

Table 3. Analysis of variance results of the radial intrinsic gas permeability versus densification time.

\begin{tabular}{ccccccc}
\hline Source & $\begin{array}{c}\text { Sum of } \\
\text { Squares }\end{array}$ & $\begin{array}{c}\text { Degrees of } \\
\text { Freedom }\end{array}$ & $\begin{array}{c}\text { Mean } \\
\text { Square }\end{array}$ & $\begin{array}{c}F \\
\text { Value }\end{array}$ & $\begin{array}{c}p \\
\text { Value }\end{array}$ & Remarks \\
\hline $\begin{array}{c}\text { Densification time (data after } \\
\text { logarithmic transformation treatment) }\end{array}$ & 5.9 & 9 & 0.66 & 22.61 & $<0.0001$ & Significant \\
\hline
\end{tabular}

Table 4. Radial intrinsic gas permeability of the control and samples densified for different times.

\begin{tabular}{cccc}
\hline $\begin{array}{c}\text { Treatment } \\
\text { Time (min) }\end{array}$ & $\begin{array}{c}\text { Oven-Dry Density } \\
\left(\mathbf{k g} / \mathbf{m}^{\mathbf{3}} \mathbf{)}(\mathbf{n}=\mathbf{3})\right.\end{array}$ & $\begin{array}{c}\text { Intrinsic Gas Permeability } \\
\left(\mathbf{m}_{\text {air }}^{\mathbf{3}} \mathbf{m}_{\mathbf{w o o d}}^{-\mathbf{1}}\right)(\mathbf{n}=\mathbf{3})\end{array}$ & $\begin{array}{c}\text { Intrinsic Gas Permeability (after } \\
\text { Logarithm Transformation) }\end{array}$ \\
\hline 0 & $694.3(4.1)^{\mathrm{c}, *}$ & $5.93 \times 10^{-17}\left(2.57 \times 10^{-18}\right)$ & $-16.23^{\mathrm{a}, *}$ \\
5 & $848.6(82.8)^{\mathrm{b}}$ & $1.02 \times 10^{-17}\left(4.71 \times 10^{-18}\right)$ & $-17.02^{\mathrm{b}}$ \\
10 & $845.4(76.1)^{\mathrm{b}}$ & $9.74 \times 10^{-18}\left(2.48 \times 10^{-18}\right)$ & $-17.02^{\mathrm{b}}$ \\
15 & $917.3(61.0)^{\mathrm{a}, \mathrm{b}}$ & $9.53 \times 10^{-18}\left(4.95 \times 10^{-18}\right)$ & $-17.06^{\mathrm{b}}$ \\
20 & $948.3(106.2)^{\mathrm{a}, \mathrm{b}}$ & $8.40 \times 10^{-18}\left(4.19 \times 10^{-18}\right)$ & $-17.12^{\mathrm{b}, \mathrm{c}}$ \\
25 & $947.1(43.5)^{\mathrm{a}, \mathrm{b}}$ & $4.28 \times 10^{-18}\left(1.76 \times 10^{-18}\right)$ & $-17.40^{\mathrm{c}, \mathrm{d}}$ \\
30 & $952.7(81.9)^{\mathrm{a}, \mathrm{b}}$ & $3.63 \times 10^{-18}\left(2.00 \times 10^{-19}\right)$ & $-17.44^{\mathrm{d}, \mathrm{e}}$ \\
35 & $1039.6(60.6)^{\mathrm{a}}$ & $2.87 \times 10^{-18}\left(1.64 \times 10^{-18}\right)$ & $-17.58^{\mathrm{d}, \mathrm{e}, \mathrm{f}}$ \\
40 & $1031.6(44.2)^{\mathrm{a}}$ & $1.95 \times 10^{-18}\left(4.8 \times 10^{-19}\right)$ & $-17.72^{\mathrm{e}, \mathrm{f}}$ \\
45 & $969.5(65.6)^{\mathrm{a}, \mathrm{b}}$ & $1.4 \times 10^{-18}\left(0.84 \times 10^{-19}\right)$ & $-17.86^{\mathrm{f}}$ \\
\hline
\end{tabular}

Values in parenthesis are standard deviations; ${ }^{*}$ Duncan's test results, average values with the same letter indicate no significant difference at $\alpha=0.05$. 


\subsection{Thermal Conductivity}

Table 5 shows the analysis of variance results of thermal conductivity versus densification time and MC. The thermal conductivity values of the control samples and densified samples are presented in Table 6. Table 5 reveals that both densification time and MC had significant effect on the thermal conductivity, but the interaction between the densification time and MC was not significant.

Table 5. Analysis of variance results of thermal conductivity versus densification time and moisture content.

\begin{tabular}{ccccccc}
\hline Source & $\begin{array}{c}\text { Sum of } \\
\text { Squares }\end{array}$ & $\begin{array}{c}\text { Degrees of } \\
\text { Freedom }\end{array}$ & $\begin{array}{c}\text { Mean } \\
\text { Square }\end{array}$ & $\begin{array}{c}\boldsymbol{F} \\
\text { Value }\end{array}$ & $\begin{array}{c}\boldsymbol{p} \\
\text { Value }\end{array}$ & $\begin{array}{c}\text { Remarks } \\
\text { Densification time }\end{array}$ \\
Moisture content & 0.014 & 9 & 0.002 & 38.88 & $<0.0001$ & Significant \\
Densification time * Moisture content & 0.001 & 2 & 0.001 & 19.18 & $<0.0001$ & Significant \\
\hline
\end{tabular}

* The interaction between densification time and moisture content.

There is a common agreement that MC has an important effect on wood thermal conductivity. As shown in Table 6, for all of treatment times, thermal conductivity increased with increasing MC. It could be found that the thermal conductivity increased by $0.5-1.5$ percent for an increase of one percent MC for densified sugar maple wood. In particular, it can be noticed that the thermal conductivity of densified samples is slightly lower than that of the control samples. This was not expected given that wood thermal conductivity generally increases with increasing density $[1,12]$. However, according to ThermoWood Handbook [23], the thermal conductivity of heat treated wood $\left(230^{\circ} \mathrm{C}, 3-5 \mathrm{~h}\right.$ ) is reduced by $20-25 \%$ compared with normal untreated softwoods (pine and spruce). The underlying reasons for the decrease in thermal conductivity after densification treatment are not entirely clear. It might be due to the alteration of the crystalline structure of cellulose chains at higher treatment temperature, resulting in strength loss and changes in its ability to conduct heat at the cellular level [16].

Table 6. Thermal conductivity of the control and samples densified at different time.

\begin{tabular}{|c|c|c|c|c|c|}
\hline $\begin{array}{l}\text { Treatment } \\
\text { Time } \\
\text { (min) }\end{array}$ & $\begin{array}{c}\text { Oven-Dry } \\
\text { Density } \\
\left(\mathrm{kg} / \mathrm{m}^{3}\right)(\mathrm{n}=3)\end{array}$ & $\begin{array}{c}\text { Thickness } \\
(\mathrm{mm}) \mathrm{MC}=0 \% \\
(\mathrm{n}=4)\end{array}$ & $\begin{array}{l}\text { Thermal Conductivity } \\
\qquad\left(\mathrm{W} \cdot \mathrm{m}^{-1} \cdot \mathrm{K}^{-1}\right) \\
(\mathrm{MC}=0 \%)(\mathrm{n}=4)\end{array}$ & $\begin{array}{l}\text { Thermal Conductivity } \\
\qquad\left(\mathrm{W} \cdot \mathrm{m}^{-1} \cdot \mathrm{K}^{-1}\right) \\
(\mathrm{MC}=6 \%)(\mathrm{n}=4)\end{array}$ & $\begin{array}{c}\text { Thermal Conductivity } \\
\left(\mathrm{W} \cdot \mathrm{m}^{-1} \cdot \mathrm{K}^{-1}\right) \\
(\mathrm{MC}=12 \%)(\mathrm{n}=4)\end{array}$ \\
\hline 0 & $694.3(4.1)^{c_{1} *}$ & $5.43(0.11)$ & $0.124(0.008)^{b, *}$ & $0.130(0.005)^{b}$ & $0.140(0.002)^{\mathrm{a}}$ \\
\hline 5 & $848.6(82.8)^{b}$ & $4.42(0.19)$ & $0.097(0.006)^{c, d, e, f, g, h}$ & $0.102(0.005)^{c, d, e, f}$ & $0.106(0.006)^{c}$ \\
\hline 10 & $845.4(76.1)^{b}$ & $4.08(0.24)$ & 0.095 (0.009) d,e,f,g,h & $0.098(0.010)^{c, d, e, f, g, h}$ & $0.103(0.009)^{c, d, e}$ \\
\hline 15 & $917.3(61.0)^{a, b}$ & $3.78(0.10)$ & $0.096(0.009)^{c, d, e, f, g, h}$ & $0.099(0.009)^{c, d, e, f, g}$ & $0.105(0.008)^{\mathrm{c}, \mathrm{d}}$ \\
\hline 20 & $948.3(106.2)^{a, b}$ & $3.75(0.16)$ & $0.094(0.005)^{\mathrm{e}, \mathrm{f}, \mathrm{g}, \mathrm{h}}$ & $0.096(0.005)^{c, d, e, f, g, h}$ & $0.101(0.005)^{c, d, e, f, g}$ \\
\hline 25 & $947.1(43.5)^{a, b}$ & $3.62(0.15)$ & $0.092(0.008)^{e, f, g, h}$ & $0.094(0.007)$ d,e,f,g,h & $0.099(0.008)^{c, d, e, f, g}$ \\
\hline 30 & $952.7(81.9)^{a, b}$ & $3.60(0.10)$ & $0.091(0.004)^{f, g, h}$ & $0.094(0.002)$ d,e,f,g,h & $0.099(0.002){ }^{c, d, e, f, g}$ \\
\hline 35 & $1039.6(60.6)^{a}$ & $3.63(0.09)$ & $0.090(0.002)^{g, h}$ & $0.093(0.002)$ e,f,g,h & $0.099(0.004)^{c, d, e, f, g}$ \\
\hline 40 & $1031.6(44.2)^{\mathrm{a}}$ & $3.56(0.12)$ & $0.095(0.005) \mathrm{d}, \mathrm{e}, \mathrm{f}, \mathrm{g}, \mathrm{h}$ & $0.097(0.005)^{c, d, e, f, g, h}$ & $0.100(0.006)^{c, d, e, f, g}$ \\
\hline 45 & $969.5(65.6)^{a, b}$ & $3.44(0.06)$ & $0.088(0.007)^{h}$ & $0.093(0.004)^{e, f, g, h}$ & $0.096(0.005)^{c, d, e, f, g, h}$ \\
\hline
\end{tabular}

Values in parenthesis are standard deviations; ${ }^{*}$ Duncan's test results, average values with the same letter indicate no significant difference at $\alpha=0.05$.

\section{Discussion and Conclusions}

THM is a feasible process to increase significantly the density of maple wood in a relatively short time. Most of the oven-dry density increase occurred within the first 5-15 min of treatment. However, the oven-dry density did not show a linear increase with the decrease of thickness. The samples, densified for $10 \mathrm{~min}$, showed a higher density in the core than at the surface, which might have been caused by the large springback after the press opening. The heat distribution across the transverse direction was more homogeneous for samples densified for a longer time with steam. The intrinsic gas permeability of the control samples was 5 to 40 times higher than that of densified wood. This indicated that the void volume of wood reduced notably after the densification treatment. 
The thermal conductivity increased by a $0.5-1.5 \%$ increase of moisture content for densified sugar maple wood. The thermal conductivity of densified samples was lower than that of the control samples. The densification time had significant effects on oven-dry density and gas permeability. Both densification time and moisture content had significant effects on thermal conductivity, but their interaction effect was not significant.

Author Contributions: Q.F. carried out the experimental tests and prepared the manuscript. A.C. and A.L. contributed to the experimental design and revised the manuscript. All authors read, discussed and approved the final manuscript.

Funding: This research was funded by the Natural Sciences and Research Council of Canada (NSERC) for funding this research under Discovery Grant No. 121954-2012.

Acknowledgments: The authors thank David Lagueux for technical assistance with the densification process.

Conflicts of Interest: The authors declare no conflict of interest.

\section{References}

1. Siau, J.F. Transport Processes in Wood; Springer: Heidelberg, Germany, 1984; ISBN 13:978-3-642-69215-4.

2. Dai, C.P.; Yu, C.M.; Zhou, X.Y. Heat and mass transfer in wood composite panels during hot pressing. Part II. Modeling void formation and mat permeability. Wood Fiber Sci. 2005, 37, 242-257.

3. Comstock, G.L. Directional permeability of softwoods. Wood Fiber Sci. 2007, 1, 283-289.

4. Denisov, O.B.; Anisov, P.P.; Zuban, P.E. Untersuchung der permeabilität von spanvliesen. Holztechnologie 1975, 16, 10-14.

5. Hata, T.; Kawai, S.; Ebihara, T.; Sasaki, H. Production of particleboards with steam-injection press. Press V. Effects of particle geometry on temperature behaviors in particle mats and on air permeabilities of boards. Mokuzai Galdcaishi 1993, 39, 161-168.

6. Von Haas, G.; Steffen, A.; Frühwald, A. Permeability of fibre, particle and strand mats for gas. Holz Roh Werkst. 1998, 56, 386-392.

7. Lihra, T.; Cloutier, A.; Zhang, S.Y. Longitudinal and transverse permeability of balsam fir wetwood and normal heartwood. Wood Fiber Sci. 2000, 32, 164-178.

8. García, R.A.; Cloutier, A. Characterization of heat and mass transfer in the mat during the hot pressing of MDF panels. Wood Fiber Sci. 2005, 37, 23-41.

9. Defo, M.; Cloutier, A.; Fortin, Y. Modeling vacuum-contact drying of wood: The water potential approach. Dry. Technol. 2000, 18, 1737-1778. [CrossRef]

10. Thömen, H. Modeling the Physical Processes in Natural Fiber Composites during Batch and Continuous Pressing. Ph.D. Thesis, Oregon State University, Corvallis, OR, USA, May 2000.

11. Gu, H.M.; Zink-Sharp, A. Geometric model for softwood transverse thermal conductivity. Part I. Wood Fiber Sci. 2005, 37, 699-711.

12. Simpson, W.; TenWolde, A. Physical properties and moisture relations of wood. In Wood Handbook: Wood as an Engineering Material; Ross, R.J., Ed.; USDA Forest Service, Forest Products Laboratory: Madison, WI, USA, 1999; pp. 3-17.

13. Troppová, E.; Švehlík, M.; Tippner, J.; Wimmer, R. Influence of temperature and moisture content on the thermal conductivity of wood-based fibreboards. Mater. Struct. 2015, 48, 4077-4083. [CrossRef]

14. Griffiths, E.; Kaye, G.W.C. The measurement of thermal conductivity. Proc. R. Soc. A 1923, 104, 71-98. [CrossRef]

15. MacLean, J.D. Thermal conductivity of wood. Heat. Pip. Air Cond. 1941, 13, 380-391.

16. Suleiman, B.M.; Larfeldt, J.; Leckner, B.; Gustavsson, M. Thermal conductivity and diffusivity of wood. Wood Sci. Technol. 1999, 33, 465-473. [CrossRef]

17. Haselein, C.R. Numerical Simulation of Pressing Wood-Fiber Composites. Ph.D. Thesis, Oregon State University, Corvallis, OR, USA, January 1998.

18. De Moura, L.F.; Hernández, R.E. Evaluation of varnish coating performance for two surfacing methods on sugar maple wood. Wood Fiber Sci. 2005, 37, 355-366.

19. Fang, C.H.; Mariotti, N.; Cloutier, A.; Koubaa, A.; Blanchet, P. Densification of wood veneers by compression combined with heat and steam. Eur. J. Wood Wood Prod. 2012, 70, 155-163. [CrossRef] 
20. Fu, Q.; Cloutier, A.; Laghdir, A. Optimization of the thermo-hygromechanical (THM) process for sugar maple wood densification. BioResources 2016, 11, 8844-8859. [CrossRef]

21. Siau, J.F. Wood: Influence of Moisture on Physical Properties; Department of Wood Science and Forest Products, Virginia Polytechnic Institute and State University: Blacksburg, VA, USA, 1995; ISBN 13:9780962218101-10:0962218103.

22. Fu, Q.; Cloutier, A.; Laghdir, A. Effects of heat and steam on the mechanical properties and dimensional stability of thermo-hygromechanically densified sugar maple wood. BioResources 2017, 12, 9212-9226. [CrossRef]

23. Finnish ThermoWood Association. ThermoWood Handbook; Finnish ThermoWood Association: Helsinki, Finland, 2003.

(C) 2018 by the authors. Licensee MDPI, Basel, Switzerland. This article is an open access article distributed under the terms and conditions of the Creative Commons Attribution (CC BY) license (http:// creativecommons.org/licenses/by/4.0/). 